\title{
PENENTUAN HARGA POKOK PRODUKSI JAMUR DENGAN METODE FULL COSTING PADA CELEBES MUSHROOM FARM
}

\author{
${ }^{1}$ Mashud, ${ }^{2}$ Askar, ${ }^{3}$ Yuliana \\ ${ }^{1,2}$ Sistem Informasi, STMIK AKBA, ${ }^{3}$ Komputerisasi Akuntansi, STMIK AKBA \\ Email: ${ }^{1}$ mashud@akba.ac.id
}

DOI: $\underline{\text { https://doi.org/10.46880/jmika.Vol4No1.pp60-66 }}$

\begin{abstract}
Companies in determining the selling price must calculate the cost of production accurately. Celebes Mushroom Farm in calculating the cost of production is done by counting manually. This research was conducted to make an application that can provide information about the overall costs incurred by Celebes Mushroom Farm in producing mushrooms. The cost calculation used the Full Costing method with Delphi 7.0 as the programming language and MySQ used in the database. Data collection by interviewing and observing techniques at Celebes Mushroom Farm and by library research. From the results of the design of the application of the cost of production, can record and calculate the cost of raw materials, labor, and fixed and variable factory overhead by computerized. And the implementation of the calculation of the cost of production using the full costing method shows that this application can calculate the cost of production accurately.
\end{abstract}

Keyword: Application, Full Costing, Cost of Goods Manufactured, Mushroom

\begin{abstract}
ABSTRAK
Perusahaan dalam menetapkan harga jual harus menghitung harga pokok produksi dengan akurat. Celebes Mushroom Farm dalam menghitung harga pokok produksi dilakukan dengan cara menghitung manual. Penelitian ini dilakukan untuk membuat aplikasi yang dapat memberikan informasi tentang keseluruhan biaya yang dikeluarkan oleh Celebes Mushroom Farm dalam memproduksi jamur. Perhitungan biaya digunakan metode Full Costing dengan Delphi 7.0 sebagai bahasa pemrograman dan MySQ yang digunakan dalam basisdata. Pengumpulan data dengan teknik mewawancara dan observasi di Celebes Mushroom Farm serta dengan studi pustaka. Dari hasil perancangan aplikasi harga pokok produksi ini, dapat melakukan pencatatan dan penghitungan biaya bahan baku, tenaga kerja, dan overhead pabrik tetap dan variable secara terkomputerisasi. Dan implementasi dari aplikasi penghitungan harga pokok produksi dengan menggunkan metode full costing menunjukkan bahwa aplikasi ini dapat menghitung harga pokok produksi dengan akurat
\end{abstract}

Kata Kunci: Aplikasi, Full Costing, Harga Pokok Produksi, Jamur

\section{PENDAHULUAN}

Perusahaaan di era teknologi untuk dapat bersaing harus meningatkan efektivitas dan efisiensi dalam melakukan proses produksi barang dengan mengolah sumber daya dengan maksimal dan menekan biaya produksi. Hal tersebut juga tidak dapat dihindari oleh Celebes Mushroom Farm. Celebes Mushroom Farm merupakan produsen jamur konsumsi pertama di Sulawesi Selatan yang menyediakan mulai dari bibit jamur, baglog jamur, jamur segar, kunjungan dan pelatihan, terletak di Kecamatan Simbang, Kabupaten Maros dan telah berdiri sejak tahun 2010 hingga sekarang. Usaha ini melakukan proses produksi secara massal untuk memenuhi stok dan juga pesanan baglog jamur yang masuk.
Harga pokok produksi ialah cara memperhitungkan kumpulan biaya produksi yang terdiri dari bahan baku langsung, tenaga kerja langsung, dan biaya overhead pabrik (Mulyadi, 2009). Dalam memproduksi jamur konsumsi perusahaan mengeluarkan biaya produksi yang disebut dengan Harga Pokok Produksi (HPP). Namun masih ada perusahaan yang menentukan biaya produksi tidak berdasarkan tiga unsur harga pokok produksi tersebut, karena dalam menetapkan hpp, perusahaan ini hanya didasarkan pada pembebanan Biaya Bahan Baku (BBB) serta Biaya Tenaga Kerja Langsung (BTK) tidak menghitung penggunaan Biaya Overhead Pabrik (BOP).

Perusahaan yang tidak memiliki perhitungan biaya produksi secara pasti akan mengalami kesulitan dalam menghitung laba yang di peroleh dari suatu 
barang yang terjual, ini disebabkan karena perhitungan untuk mendapatkan harga pokok masih belum mencakup semua elemen biaya yang di keluarkan dalam proses produksi. Ini tentu berpengaruh pada harga jual yang diberikan kepada pelanggan serta ketidakstabilan laba yang diperoleh. Begitupun yang terjadi pada Celebes Mushroom Farm, dalam menentukan harga jual hanya berdasarkan besar pemakaian bahan, harga pasar, dan gaji tenaga kerja di tambah dengan keuntungan yang ingin di peroleh.

Perhitungan HPP secara akurat merupakan hal yang harus dilakukan untuk menghindari overcosting atau undercosting dalam menetapkan harga jual. Celebes Mushroom Farm dalam menentukan biaya produksi belum berdasarkan tiga unsur HPP yaitu BBB, BTK dan BOP. Salah satu metode penentuan HPP yang dapat dterapkan perusahaan adalah metode full costing. Dengan metode ini perusahaan dapat menghitung semua elemen biaya produksi ke dalam harga pokok, yang terdiri dari BBB, BTK, dan BOP tetap dan variable.

Penelitian ini dilakukan untuk membuat aplikasi yang dapat memberikan informasi tentang keseluruhan biaya yang dikeluarkan oleh Celebes Mushroom Farm dalam memproduksi jamur. Sehingga Celebes Mushroom Farm dapat menghitung harga pokok produksi dengan akurat

\section{STUDI PUSTKA}

\section{Aplikasi}

Aplikasi adalah program yang berisikan isntruksi-instruksi dalam mengolah data. Secara umum aplikasi dapat diartikan suatu proses mengubah cara manual ke komputer dengan membuat sistem atau program untuk dapat data diolah lebih berdaya guna secara optimal (Mashud \& Herni, 2018).

\section{Akuntansi Biaya}

Akuntansi biaya dapat didefinisikan sebagai suatu proses mencatat, menggolongkan, meringkas dan menyajikan biaya dalam membuat dan menjual barang atau jasa, dengan cara-cara tertentu, serta interpretasi terhadapnya (Mulyadi, 2009). Proses akuntansi biaya ditujukan untuk memenuhi kebutuhan pemakai intenal perusahaan dan juga untuk pihak eksternal perusahaan. Dalam akuntansi biaya ada tiga tujuan pokok yaitu: penentuan harga pokok produk, pengendalian biaya, dan pengambilan keputusan.

\section{Biaya}

Suatu pengorbanan kekayaan yang diukur berdasarkan satuan uang untuk memperoleh suatu barang atau jasa dan telah terjadi atau yang kemungkinan akan terjadi dengan maksud tujuan tertentu disebut biaya (Mulyadi, 2009). Dalam pengertian biaya terdapat empat unsur, yakni:

a. Biaya adalah pengorbanan kekayaan

b. Diukur berdasarkan uang.

c. Merupakan pengorbanan yang telah terjadi atau yang kemungkinan akan terjadi.

d. Ada tujuan tertentu.

\section{Harga Pokok Produksi}

Harga pokok produksi (HPP) adalah biaya yang terjadi dalam rangka untuk menghasilkan barang jadi atau produk dalam perusahaan pabrikan (Muhadi, 2019). Tujuan perusahaan dalam menghitung atau menentukan harga pokok produksi yaitu untuk penilaian kembali harga jual yang telah ditentukan. Komponen untuk menentukan harga pokok produksi adalah biaya produksi yang digolongkan menjadi tiga, yaitu:

a. Biaya bahan baku (BBB)

b. Biaya Tenaga Kerja Langsung (BTKL)

c. Biaya Overhead Pabrik (BOP)

\section{Biaya Bahan Baku}

Menurut Ermayati (Ilham \& Sudarno, 2013), bahan baku yaitu berbagai ragam bahan yang diolah menjadi produk jadi dan penggunaannya dapat ditelusuri. Biaya bahan baku (BBB) adalah harga perolehan berbagai ragam bahan mentah yang dipakai dalam membuat produk. Biaya ini mencakup harga pokok dari keseluruhan bahan yang secara praktis dapat di masukkan sebagai bahan dari produk jadi. Misalnya, terigu pada usaha roti, papan atau kayu pada perusahaan furniture, benang pada industri tenung, kain pada industri tekstil, rotan pada industri kerajinan rotan. Tidak semua bahan yang dipakai dalam pembuatan suatu produk dikategorikan sebagai bahan baku. Misalnya Paku pada industri furniture, mungkin tidak dikategorikan sebagai bahan baku. Bahan-bahan yang nilainya relatif kecil seperti itu disebut bahan penolong dan dikategorikan sebagai bagian produksi tak langsung.

\section{Biaya Tenaga Kerja Langsung}

Tenaga kerja merupakan usaha fisik atau pikiran yang dikeluarkan oleh pekerja atau pengawai dalam mengolah produk. Biaya tenaga kerja yaitu harga yang dikeluarkan untuk penggunaan tenaga kerja manusia tersebut, (Mulyadi, 2009).

Pengelompokkan kegiatan tenaga kerja dibedakan menjadi beberapa pengakuan dalam 
menghitung biaya tenaga kerja. Pengelompokkan menurut hubungan dengan produk. Dalam kaitannya dengan produk, terdapat tenaga kerja langsung. Tenaga kerja langsung yaitu semua pekerja atau pegawai yang secara langsung ikut serta proses pengolahan bahan baku menjadi produk jadi, yang jasanya dapat diusut secara langsung pada produk, dan yang upahnya merupakan bagian yang besar dalam menghasilkan produk. Upah tenaga kerja langsung diperlukan sebagai biaya tenaga kerja langsung dan diperhitungkan langsung menjadi unsur biaya produksi.

Cara menghitung gaji dan upah pekerja atau pegawai dalam perusahaan yaitu mengalikan tarif upah dengan jumlah jam kerja pekerja atau pegawai tersebut. Dengan demikian, untuk menentukan upah seorang pekerja atau pegawai diperlukan data jumlah jam kerjanya selama periode waktu tertentu.

\section{Biaya Overhead Pabrik}

Biaya Overhead Pabrik (BOP) dapat dikelompokkan menjadi enam menurut sifatnya yaitu (Mulyadi, 2009) :

a. Biaya bahan penolong

b. Biaya perbaikan dan pemeliharaan

c. Biaya tenaga kerja tak langsung

d. Biaya yang ditimbulkan dari akibat penilaian terhadap aset tetap

e. Biaya yang ditimbulkan dari akibat berlalunya waktu

f. Biaya overhead pabrik lain yang secara langsung memerlukan pengeluaran uang tunai.

Dilihat dari perilaku bagian-bagian BOP dalam keterkaitannya dengan jumlah kegiatan, BOP dapat dibagi menjadi tiga kelompok, yaitu:
a. BOP tetap
b. BOP variable
c. BOP semivariable

\section{Metode Penentuan Harga Pokok Produksi}

Metode penentuan biaya yaitu suatu cara menghitung semua jenis biaya ke dalam biaya produksi. Dalam memperhitungkan bagian biaya terdapat dua jenis metode penentua yang dapat digunakan yaitu full costing dan variable costing (Mulyadi, 2009),

\section{Full Costing}

Full costing merupakan metode penentuan HPP yang menghitung semua jenis BBB, BTKL dan BOP baik yang berperilaku variabel atau tetap.
HPP yang dihitung menggunakan metode full costing terdiri dari unsur biaya produksi (BBB, BTKL, BOP variabel, dan BOP tetap) ditambah dengan biaya yang tidak berpengaruh langsung terhadap produksi (biaya pemasaran, biaya administrasi dan umum).

\section{Variabel Costing}

Variable costing merupakan metode penentuan HPP yang hanya menghitung biaya produksi yang berperilaku variabel kedalam HPP yang terdiri dari BBB, BTKL dan BOP variabel.

HPP yang dihitung dengan menggunakan metode variable costing terdiri dari unsur HPP variabel (BBB, BTKL, dan BOP variabel) ditambah dengan biaya yang tidak berpengaruh langsung terhadap produksi variabel (biaya pemasaran variabel, dan biaya administrasi dan umum variabel)

\section{Manfaat Informasi Harga Pokok Produksi}

Manfaat informasi HPP menurut Mulyadi (Batubara, 2013), yaitu :

a. Menentukan harga jual produk.

b. Memantau realisasi biaya produksi.

c. Menghitung laba atau rugi periodik.

d. Menentukan harga pokok persediaan produk jadi dan produk dalam proses yang disajikan dalam neraca.

\section{Jamur Tiram}

Salah satu komuditas yang banyak disukai oleh masyarakat saat ini adalah jamur tiram. Jamur tiram menjadi bahan dalam memenuhi kebutuhan pangan. Hal ini dapat dilihat dari jumlah permintaan yang mengalami peningkatan setiap tahunnya. Karena banyak peminat menjadikan permintaan jamur tiram semakin meningkat sehingga masih belum dapat dipenuhi dan masih banyak yang di datangkan dari luar daerah. Masyarkat diharapkan melakukan budidaya jamur tiram (Sitompul et al., 2017).

\section{METODE PENELITIAN}

\section{Analisis Sistem yang Berjalan}

Tahap analisis sistem yang berjalan merupakan tahapan dalam melakukan penentuan masalah awal pada sistem yang masih manual dan diuraikan pada document flow diagram yang berjalan. 


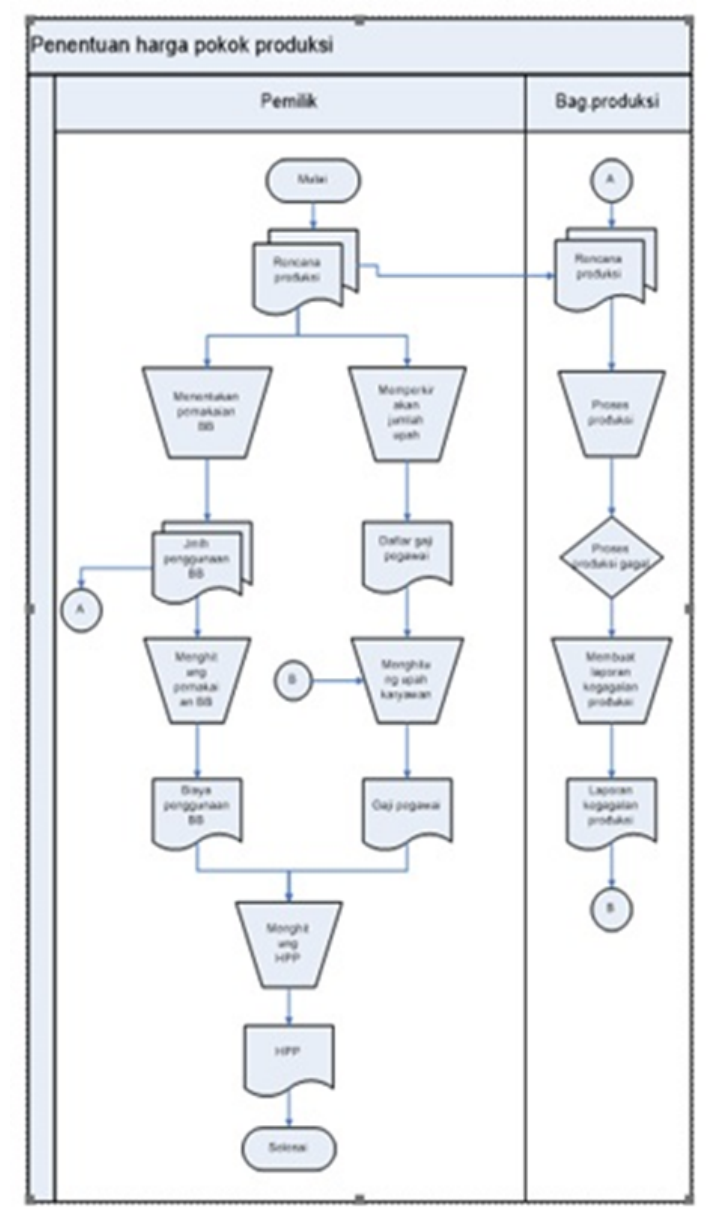

Gambar 1. Document Flow Diagram Yang Berjalan

\section{Teknik Pengumpulan Data}

Pengumpulan data dengan dilakukan dengan teknik mewawancara dan observasi di Celebes Mushroom Farm untuk mencari informasi mengenai sistem yang sedang berjalan pada Celebes Mushroom Farm serta dengan studi pustaka.

\section{Contoh Perhitungan HPP dengan Metode Full Costing}

Contoh kasus perhitungan HPP pada usaha jamur menggunakan metode full costing adalah sebagai berikut :

Tabel 1. Bahan Baku

\begin{tabular}{|l|l|r|}
\hline Nama Bahan Baku & \multicolumn{1}{|c|}{ Satuan } & Biaya \\
\hline Serbuk Kayu & $18 \mathrm{Karung}$ & Rp. 54.000 \\
\hline Dedak Halus & $11 \mathrm{~kg}$ & Rp. 22.000 \\
\hline Kapur & $2 \mathrm{Kg}$ & Rp. 2.000 \\
\hline Air & - & \\
\hline Bibit F2 & 10 Botol & Rp. 150.000 \\
\hline Plastik PP & $2 \mathrm{Kg}$ & Rp. 30.000 \\
\hline Tali raffia & $1 \mathrm{Rol}$ & Rp. 18.000 \\
\hline Spirtus & $1 \mathrm{Liter}$ & Rp. 25.000 \\
\hline Alkohol & $1 \mathrm{Liter}$ & Rp. 35.000 \\
\hline Dedak Jagung & $2 \mathrm{Kg}$ & Rp. 7.000 \\
\hline
\end{tabular}

\begin{tabular}{|l|l|r|}
\hline EM4 & 1 Liter & Rp. 20.000 \\
\hline Gula Pasir & 1 Liter & Rp. 12.000 \\
\hline Karet & 1 Bungkus & Rp. 15.000 \\
\hline Koran & $1 \mathrm{Kg}$ & Rp. 5.000 \\
\hline Ring Baglog & 2 Batang & Rp. 30.000 \\
\hline Tabung Gas & 3 Tabung & Rp. 60.000 \\
\hline \multicolumn{2}{|c|}{ Total } & Rp. 485.000 \\
\hline
\end{tabular}

Tabel 2. Tenaga Kerja

\begin{tabular}{|l|c|c|r|}
\hline $\begin{array}{c}\text { Nama } \\
\text { Tenaga } \\
\text { Kerja }\end{array}$ & $\begin{array}{c}\text { Jml } \\
\text { Jam } \\
\text { Kerja } \\
\text { (Jam) }\end{array}$ & $\begin{array}{c}\text { Tarif } \\
\text { /Jam }\end{array}$ & Total Biaya \\
\hline Pekerja 1 & 3 & Rp. 4.000 & Rp. 12.000 \\
\hline Pekerja 2 & 3 & Rp. 4.000 & Rp. 12.000 \\
\hline Pekerja 3 & 7 & Rp. 6.000 & Rp. 126.000 \\
\hline Pekerja 4 & 21 & Rp. 5.500 & Rp. 115.500 \\
\hline Pekerja 5 & 21 & Rp. 5.500 & Rp. 115.500 \\
\hline Pekerja 6 & 21 & Rp. 5.000 & Rp. 105.000 \\
\hline Pekerja 7 & 21 & Rp. 5.000 & Rp. 105.000 \\
\hline Pekerja 8 & 21 & Rp. 5.000 & Rp. 105.000 \\
\hline Pekerja 9 & 21 & Rp. 5.000 & Rp. 105.000 \\
\hline Pekerja 10 & 21 & Rp. 5.000 & Rp. 105.000 \\
\hline Pekerja 11 & 100 & Rp. 5.000 & Rp. 500.000 \\
\hline Pekerja 12 & 100 & Rp. 4.000 & Rp. 400.000 \\
\hline Pekerja 13 & 125 & Rp. 12.000 & Rp. 1.500.000 \\
\hline Pekerja 14 & 125 & Rp. 5.000 & Rp. 625.000 \\
\hline \multicolumn{3}{|l|}{ Total } & Rp. 3.931.000 \\
\hline
\end{tabular}

Tabel 3. BOP

\begin{tabular}{|c|c|}
\hline Jenis Overhead & Biaya \\
\hline BOP Tetap & Rp. 1.450 .000 \\
\hline BOP Variabel & Rp. 3.165 .000 \\
\hline Total & Rp. 4.615 .000 \\
\hline
\end{tabular}

Perhitungan HPP dengan Metode Full Costing :

$\begin{array}{llr}\text { BBB } & = & \text { Rp. } 485.000 \\ \text { BTKL } & = & \text { Rp. } 3.931 .000 \\ \text { BOP Tetap } & = & \text { Rp. } 1.450 .000 \\ \text { BOP Variabel } & = & \text { Rp. } 3.165 .000 \\ \text { HPP } & = & \text { Rp. } 9.031 .000\end{array}$

\section{Diagram Use Case}

Dalam Diagram use case dijelaskan tentang tahap yang dapat dilakukan oleh pemilik terhadap sistem yaitu login, menampilkan menu master yang terdiri dari master BBB, master BTK, master BOP tetap dan variable. menampilkan data produksi yang terdiri dari BBB, BTK, BOP tetap dan variable. Terakhir menampilkan laporan dari perhitungan HPP. Diagram use case dari penelitian ini ditampilkan pada Gambar 2 berikut: 


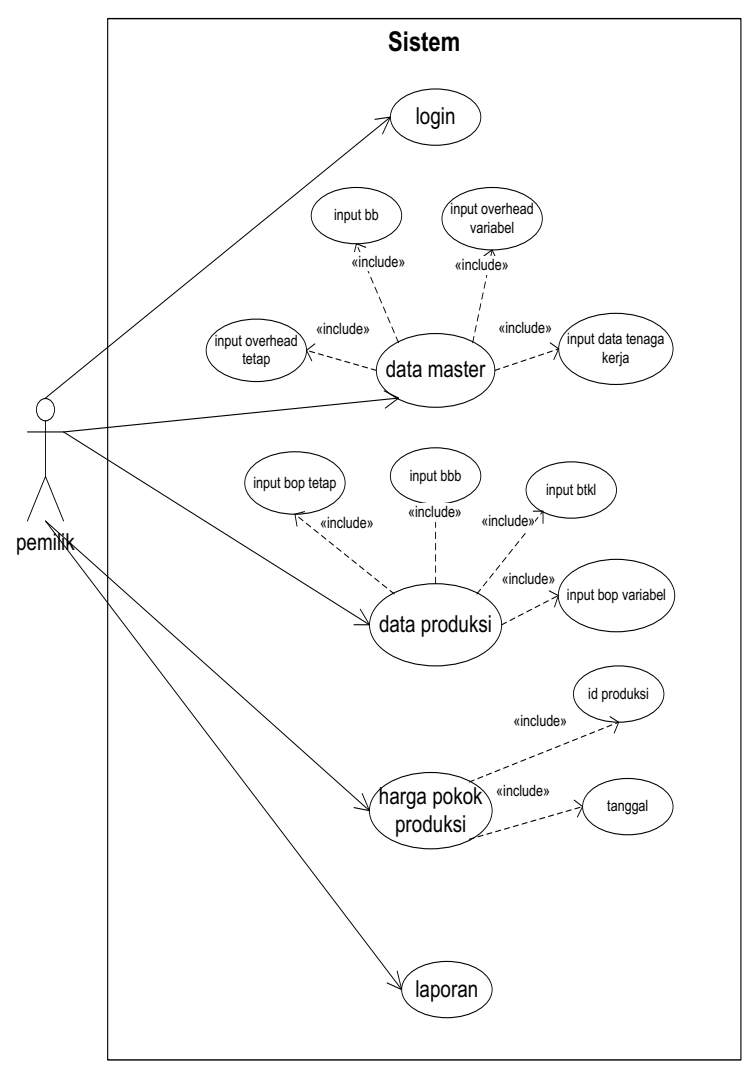

Gambar 2. Use Case Diagram

\section{HASIL DAN PEMBAHASAN}

Menu Login

User atau dalam hal ini Pemilik sebagai pengguna aplikasi pertama-tama harus login dengan memasukkan username dan password. Setelah dinyatakan sukses melakukan login maka selanjutnya sistem menampilkan menu utama. Pada gambar 3 dapat dilihat tampilan login.

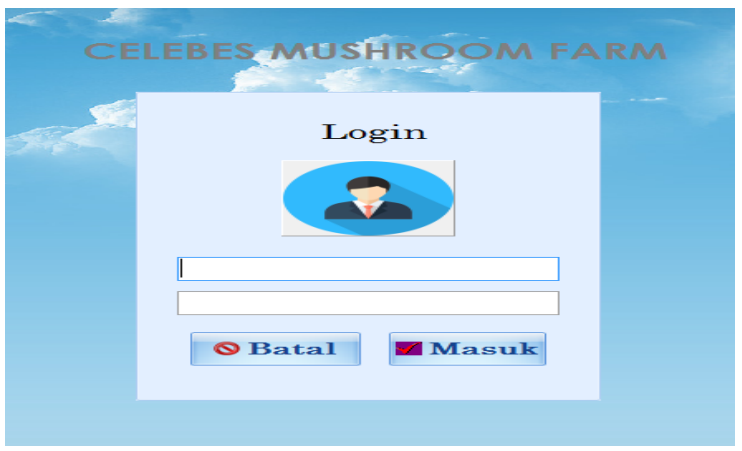

Gambar 3. Menu Login

\section{Menu Utama}

Setelah Login Sukses maka akan masuk ke menu utama. Pada menu utama akan menampilkan menu-menu yang ada dalam aplikasi, yaitu menu master, menu data produksi dan menu HPP. Pada Gambar 4, dapat di lihat tampilan menu utama.

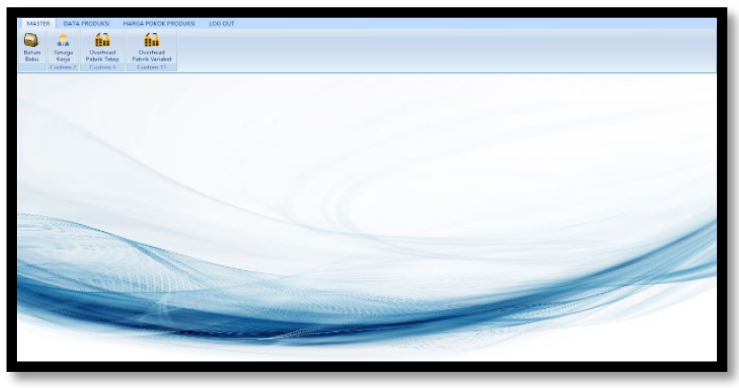

Gambar 3. Menu Utama

\section{Menu Data Master}

Menu data master akan menampilkan form untuk mengisi data seperti data Bahan Baku, data Tenaga Kerja, data Overhead Pabrik tetap dan variabel.

a. Input data $\mathrm{BBB}$

Menu data master Bahan Baku untuk melakukan penginputan semua bahan-bahan yang akan dipakai dalam proses produksi terdiri dari id bahan baku, nama bahan baku, harga dan satuan, selanjutnya klik tombol simpan. Begitupun selanjutnya sampai semua bahan baku terinput.

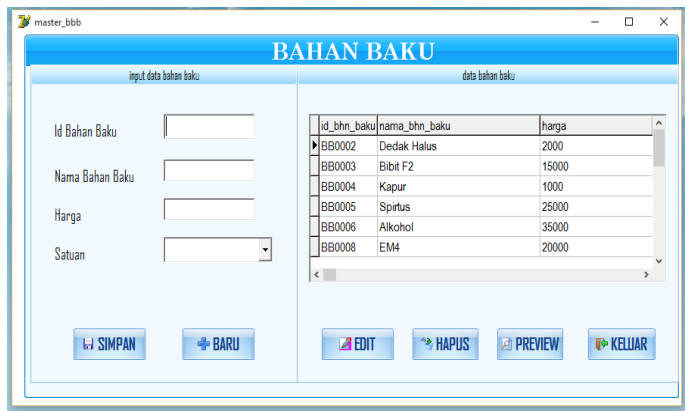

Gambar 4. Master Bahan Baku

b. Input data Tenaga Kerja

Menu data master Tenaga Kerja untuk melakukan penginputan semua nama karyawan yang terlibat dalam proses produksi terdiri dari id karyawan, nama karyawan, bagian dan tariff per jam, selanjutnya klik tombol simpan. Begitupun selanjutnya sampai semua data tenaga kerja terinput.

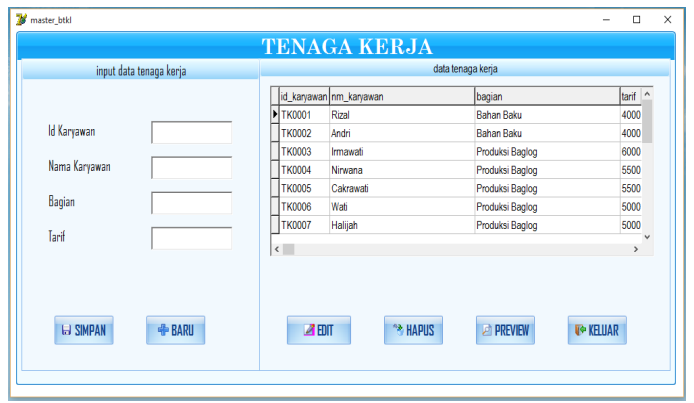

Gambar 5. Master Tenaga Kerja 
c. Input data overhead tetap

Menu data master overhead pabrik tetap untuk melakukan penginputan semua data overhead pabrik tetap terdiri dari id overhead, nama overhead, dan harga, selanjutnya klik tombol simpan. Begitupun selanjutnya sampai semua data overhead pabrik tetap terinput.

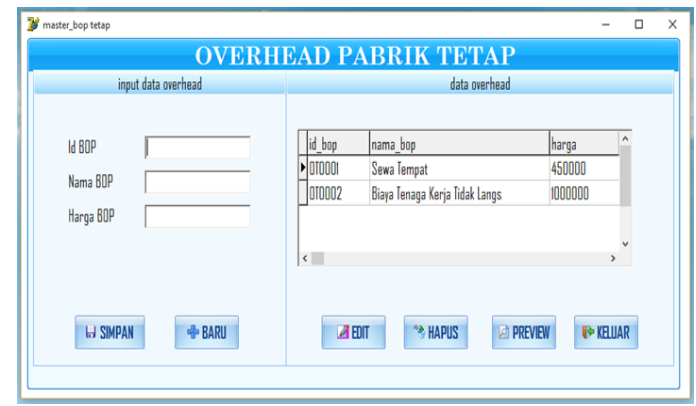

Gambar 6. Master overhead tetap

d. Input data overhead variable

Menu data master overhead pabrik Variabel untuk melakukan penginputan semua data overhead pabrik yang bersifat variable terdiri dari id overhead, nama overhead, dan harga overhead, selanjutnya klik tombol simpan. Begitupun selanjutnya sampai semua data overhead variable terinput

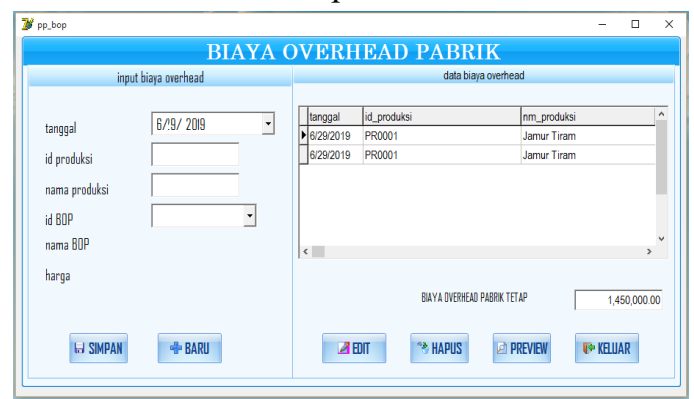

Gambar 7. Master overhead Variabel

\section{Menu Data Produksi}

Pada menu data produksi akan tampil form untuk menginput biaya-biaya yang digunakan dalam proses produksi terdiri dari BBB, BTK, BOP tetap dan BOP pabrik variable.

a. Biaya bahan baku

Pada form ini digunakan untuk melakukan penginputan jumlah bahan baku dan menghitung BBB yang digunakan dalam proses produksi.

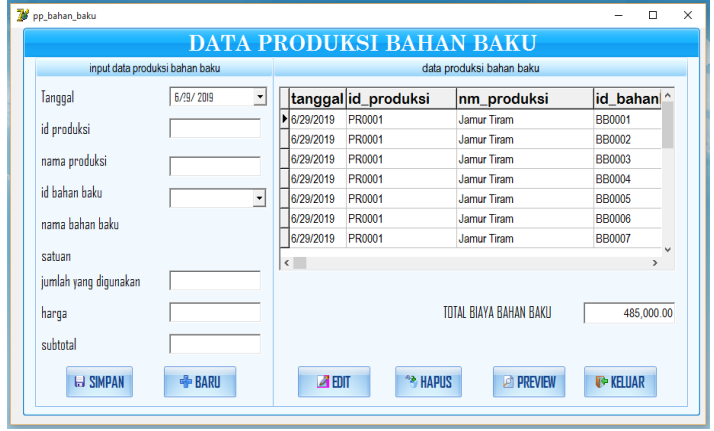

Gambar 8. Form Input BBB

b. Biaya tenaga kerja

Pada form ini digunakan untuk melakukan penginputan jumlah jam kerja dan menghitung total BTK yang digunakan selama proses produksi

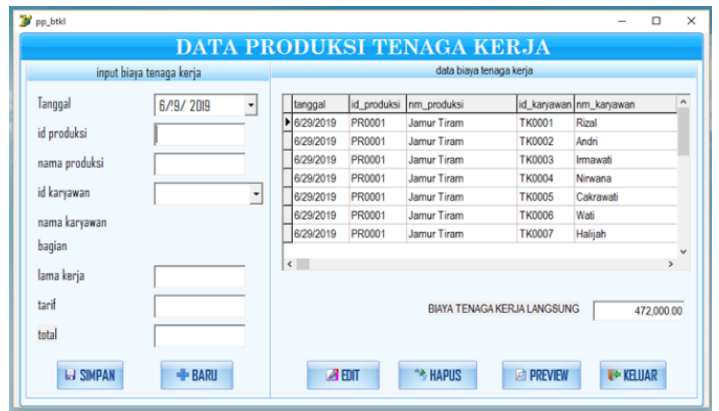

Gambar 9. Form Input BTK

c. Biaya overhead pabrik tetap

Pada form ini digunakan untuk melakukan penginputan dan menghitung jumlah BOP pabrik yang bersifat tetap.

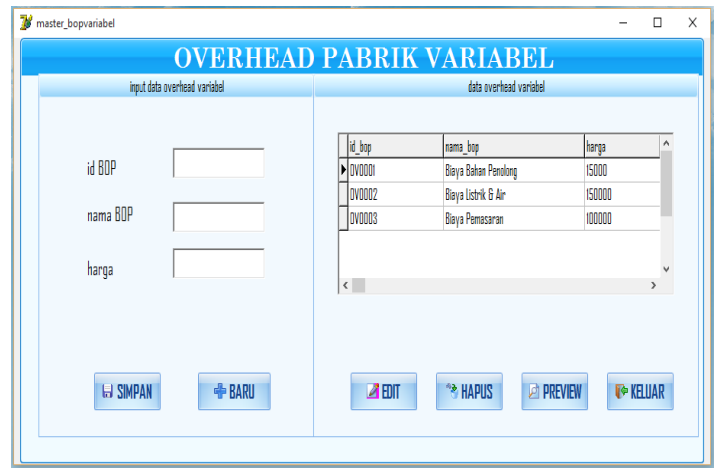

Gambar 10. Form Input BOP Tetap

d. Biaya overhead pabrik variable

Pada form ini digunakan untuk melakukan penginputan dan menghitung jumlah BOP yang bersifat variabel. 


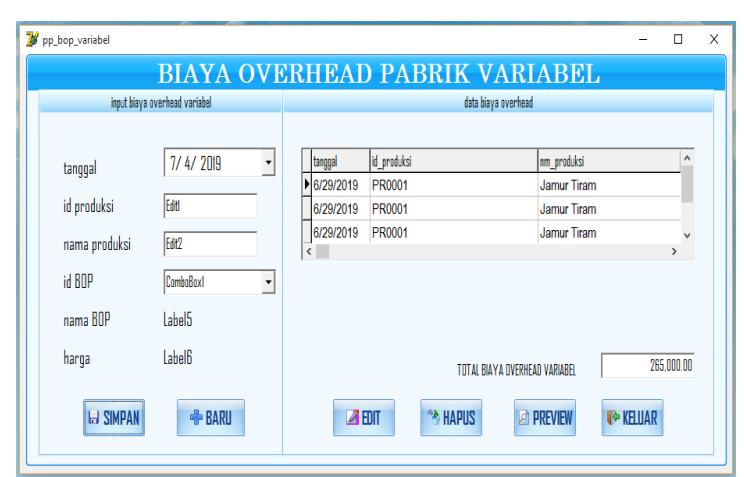

Gambar 11. Form Input BOP Variabel

\section{Menu Harga Pokok produksi}

Menu harga pokok produksi digunakan untuk mencetak laporan harga pokok produksi dengan memilih jenis produksi dan tanggal kemudian klik cetak

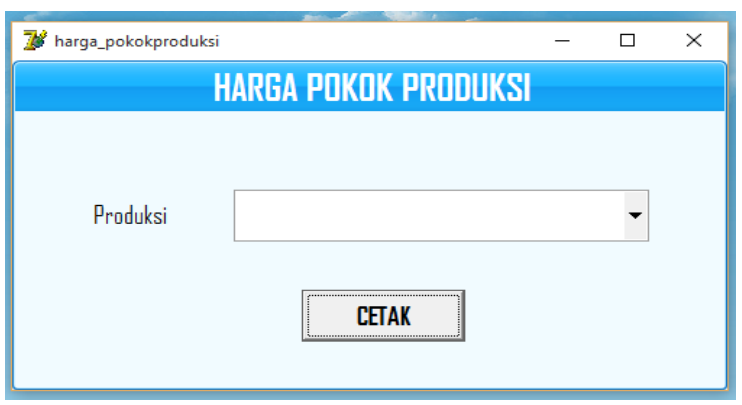

Gambar 12. Harga Pokok Produksi

\section{Laporan Harga Pokok Produksi}

Laporan harga pokok produksi menampilkan jumlah dari setiap biaya yang digunakan yaitu BBB, BTK, BOP tetap dan variable. Kemudian menampilkan jumlah dari keseluruhan biaya yang disebut dengan harga pokok produksi

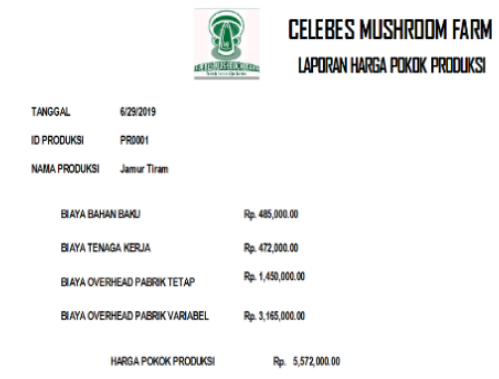

Gambar 13. Laporan Harga Pokok Produksi

\section{KESIMPULAN}

Dari hasil perancangan aplikasi harga pokok produksi ini, dapat melakukan pencatatan dan penghitungan biaya bahan baku, tenaga kerja, dan overhead pabrik tetap dan variable secara terkomputerisasi. Dan implementasi dari aplikasi penghitungan harga pokok produksi dengan menggunkan metode full costing menunjukkan bahwa aplikasi ini dapat menghitung harga pokok produksi dengan akurat

\section{DAFTAR PUSTAKA}

Batubara, H. (2013). Penentuan harga pokok produksi berdasarkan metode full costing pada pembuatan etalase kaca dan alumunium di ud. Istana alumunium manado. Jurnal EMBA: Jurnal Riset Ekonomi, Manajemen, Bisnis Dan Akuntansi, 1(3).

Ilham, I., \& Sudarno, S. (2013). Penentuan Harga Pokok Produksi Percetakan Sablon “OTAKKANAN Production” di Yogyakarta.

Mashud, M., \& Herni, H. (2018). Aplikasi Analisis Laporan Keuangan Dengan Metode Analisis Rasio Keuangan Berbasis Web Pada PT. Sinar Galesong Mandiri. Jurnal Inspiration, 8(2).

Muhadi, M. (2019). Perhitungan Harga Pokok Produksi: Sebuah Analisis Perbandingan Antara Metode Full Costing Dengan Activity Based Costing System Pada PT."Y". Jurnal Informasi, Perpajakan, Akuntansi, Dan Keuangan Publik, 5(1), 57-71.

Mulyadi, (2009). Akuntansi Biaya Edisi ke 5. Yogyakarta: UPP STIM YKPN.

Sitompul, F. T., Zuhry, E., \& Armaini, A. (2017). Pengaruh Berbagai Media Tumbuh dan Penambahan Gula (Sukrosa) terhadap Pertumbuhan Jamur Tiram Putih (Pleurotus Ostreatus). JOM Faperta, 4(2), 1-15. 